\title{
WITCHCRAFT AND ANTI-WITCHCRAFT IN NUPE SOCIETY
}

\author{
S. F. NADEL
}

I

MY investigations into witchcraft among the Nupe were carried 1 out under extremely adverse conditions. In February 1932 Bida, the capital of Nupe Emirate, had seen an outbreak of witchcraft which threw the whole country into a state of gravest unrest. Three women, an alleged witch with her daughter and granddaughter, were stoned to death by the enraged people of Bida when they tried to obtain justice against their accusers. The house of one of the town notables who was involved in the case was set fire to. The town was in turmoil, and the ensuing trial before the European authorities, complicated as it was by political issues and violent party feuds, was carried out under great difficulties. It lasted three months, and ended with two death sentences and two sentences of long-term imprisonment. When I arrived in Nupe country in January 1934, these happenings were still alive in every one's memory. No wonder, then, that the people were extremely reluctant to speak about witchcraft. For a long time I found it almost impossible to obtain information on this subject, which for the natives remained so closely related to the idea of death penalties and prison. But on the other hand, such a situation made investigation only more urgent. One could estimate the strength of the belief in witchcraft among the Nupe from this incident which occurred in a Mohammedan town, in the 'enlightened' capital of a Mohammedan Emirate. And one was faced, above all, with the problem of the normal weapons which the community would possess against this power of witchcraft, with the problem of a possible original institution against witchcraft which, as it seemed, had broken down somehow, giving rise to that act of distuptive self-justice.

Notz.-This paper was originally read before the Oxford University Anthropological Society and I wish to acknowledge my indebtedness for the valuable suggestions made in the discussion, which have helped to give the article its final form. 


\section{2}

The specific concept of witchcraft, to start with, the idea of some specific supernatural power which man can become possessed of, and which is used exclusively for evil and anti-social purposes, is very clearly defined in Nupe mentality. Witchcraft is separated very distinctly from the general system of magic and magico-religious rites (kuti), it has nothing to do with the religious belief in the Highgod Sokó, it is distinguished from the general beliefs in spirits (jénü) and ghosts ( fàra), and finally it is also distinguished from the mere application of a magical substance or ' medicine' (cigbe) which brings about immediately, as it were, a certain desired effect. Yet, as we shall see, a specific type of spirit beliefs, and a specific type of 'medicine', are incorporated in the Nupe ideas on witchcraft. When we said that witchcraft is 'evil' and 'anti-social', this was said from the point of view of the natives themselves. Witchcraft is considered by everybody without exception an evil craft, deserving the heaviest punishment. Witchcraft leads invariably to one end: death. But the essential thing would be that behind the act of killing through witchcraft one would assume no understandable motives or reasons which would fit somehow into the scheme of a normally working social structure, motives such as personal enmity, or the like. An intelligible motive would never be absent where ordinary magic_-'black magic' in an often adopted terminology-turns into deadly practice. Witchcraft, however, means killing for the reason of some evil will which can be measured by no social or human standards; it means an act which is but the inevitable outcome of some initial destructive force. Yet we are anticipating. To return to witchcraft proper, the specific concept has a specific name: witchcraft is called egà, and a witch găci. But every Nupe would add at once: 'nyizagizi a-gá è-nya'gào', 'the women are the ones who practise witchcraft'. When you inquire further you learn that men can also practise witchcraft. But their power is said to be much weaker, much less specific, compared with the 'real' witchcraft of the women, and their activities do not call forth the elaborate antiwitchcraft organization which is one of the most characteristic features of Nupe society.

Let me demonstrate, first of all, the main differences between 


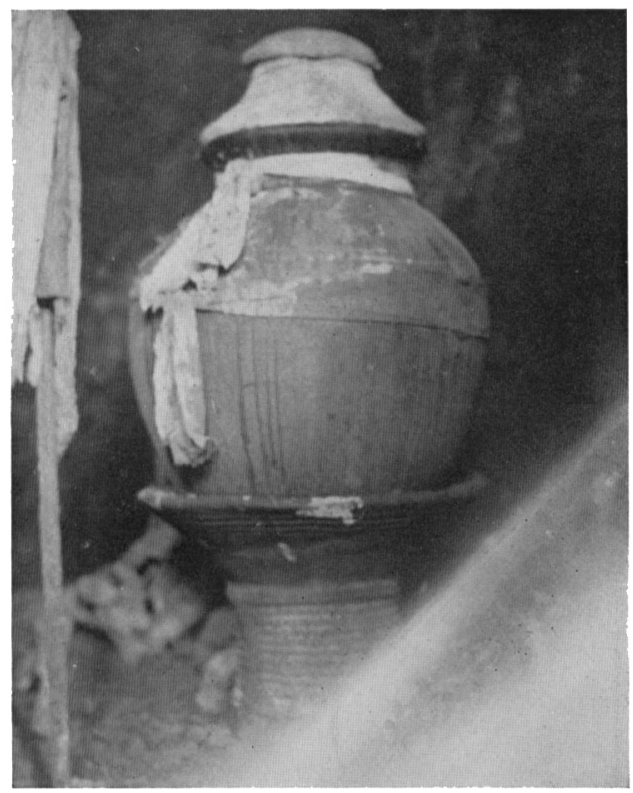

The sacred shrine of the anti-witchcraft society

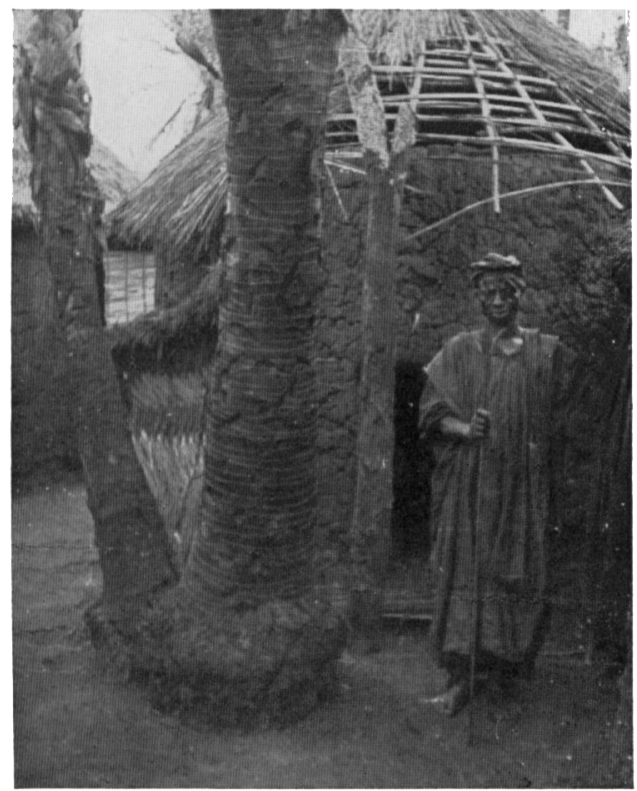

The Ndace, head of the hunters and master of the men's witchcraft 

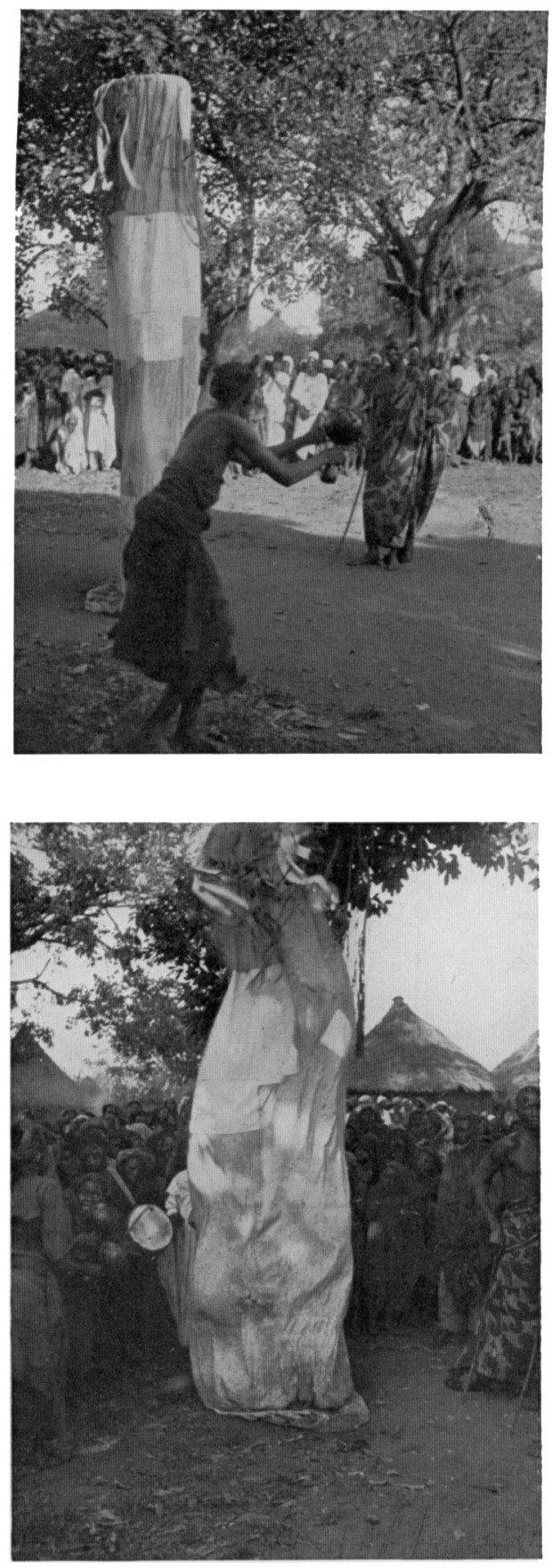

Dance of the Ndákó gbòyá mask 
WITCHCRAFT AND ANTI-WITCHCRAF'T IN NUPE SOCIETY 425 male and female witchcraft as the Nupe see it, by means of a schematic chart:

\section{Female}

Name for witch- egà, viz. găci, pl. găcizi craft and witch

Nature of witchcraft
(I) makes invisible

(2) separates 'shadow-soul' from body

(3) enables witch to recognize other witches

(4) enables witch to destroy other people's life
Male

èshè, viz. èshèci

(I) do.

(2) do., but not regularly

(3) do.

(4) enables witch to influence other people's life, but not always fatally

(s) alternating with (2), gives power over a personal spirit

Power of w. is re- medicine of bàdufu, for medicine of bàdufu, and presented in drinking and washing

One becomes a by buying secret from a felwitch

low witch or head of the witches

Alleged organiza- very strong, one speaks of tion

ènà găcizì, i.e. ' order of witches'; special official head, lelu

Application of (I) very specific, i.e. assowitchcraft ciated with night, and human soul

(2) anti-social, aim to 'eat other people's souls', i.e. aiming at other people's death number of other medicines

do.

no organization, 'head' identical with head of hunter guild

(I) not specific, admits of different applications

(2) not necessarily antisocial, includes also protection from thieves or enemies, and even harmless tricks which one plays on other people.

The common features of male and female witchcraft seem to be these: witchcraft is a power which is not hereditary, which is not an innate capacity of man, but which must be acquired specially (mostly purchased) from some one who already possesses the secret of witchcraft, preferably from the 'head' of witches or sorcerers directly. Where witchcraft is inherited, it is inherited only like knowledge or a 


\section{WITCHCRAFT AND ANTI-WITCHCRAFT IN NUPE SOCIETY}

traditional profession which is handed on from generation to generation. Witchcraft is, moreover, understood in a very concrete, materialistic, manner. It is represented in a medicine which one drinks or rubs on the body or into the eyes. Women are supposed to carry the medicine in their belt or hair. And men sorcerers have all their life to keep a special taboo: they must not eat out of a cracked calebash lest their magical power escapes for ever. As regards the supernatural capabilities with which witchcraft endows man, the common features are two: the power of making oneself invisible, and of recognizing (and accordingly protecting oneself from) fellow witches or sorcerers.

This last point allows us a first insight into the psychological forces embodied in the witchcraft beliefs. It stresses the fact that witches and sorcerers are mysterious personalities, working 'in the dark' in the widest sense, and unrecognizable to everybody except to each other. You cannot, so to speak, trace witches in plain daylight, and take precautionary measures against them. Even the criteria by which a witch recognizes a fellow witch are far from concrete and tangible; fire is said to come out of the mouth of every witch; and tears to spring from the eyes of a witch who happens to meet a more powerful colleague. The workaday world-existence of witches, then, is hardly tangible; their concrete activities (the ' eating of souls') impossible to identify. Witchcraft creates an imaginary world of cause and effect to which the criteria of our own reality are almost inapplicable. Witchcraft constitutes, in one word, a belief which protects itself from being 'found out'.

At this point, however, the divergence between male and female witchcraft begins. Complete secrecy, invisibility, and the separation of the soul from the body (the theoretical background of which belief we shall examine presently), has real and exclusive significance only for the activities of the gácizi, the women witches. Invisibility enables them to carry out what constitutes the specific and only work of their kind, namely the secret nightly visits to other people's houses whose life they destroy in the manner of vampires, or, in native terminology, whose 'soul they eat'. For the èshèci, the man-witch, this type of work means only an occasional, even exceptional, occupation. Theoretically he may be able to do what the women do, but on the whole he would devote his power rather to other, less objectionable, and certainly 
WITCHCRAFT AND ANTI-WITCHCRAFT IN NUPE SOCIETY 427 much more purposive, activities. He would put up a 'medicine' in his house against thieves or private enemies. He would apply magic to an arrow or a sword making it into an unfailing weapon. Or he would utter his enemy's name under certain magical rites, thus sending him a disease, and occasionally death, from a distance. I I knew one such sorcerer, that is to say a man who was said to be a sorcerer; he himself, however, admitted only that his (dead) father had been a sorcerer. And one special ability of his father of which he would always boast was, that he could send stomach-ache to people who did not behave deferentially enough towards him.

The essential distinction between men and women witches is reflected in the different rules for the initiation into witchcraft. A man who wants to become a sorcerer would go to the ndàce, the head of the hunter guild. He would bring him presents for some time, and finally ask to buy the special medicine which would give him the power of witchcraft. Of this medicine, made by the ndăce himself of grass which he pulled out of the mouth of grazing buffaloes, the initiate drinks a little, and he washes himself with it in the master's house. Then he goes home, and repeats the same procedure every day for five days, keeping at the same time a strict sexual taboo. This ends the initiation, and he is now a new, full-fledged, and independent, sorcerer.

Now in this fact that the ndăce is supposed to be the master of witchcraft lies a special significance. The ndăce is more or less a public figure in the village. Everybody knows him, and a prospective sorcerer who frequently went to see the ndáce without being able to produce any professional or such-like reason for his visits, would soon become known too. The observation of the taboo not to eat out of a cracked calebash again involves a certain risk of making oneself known to others as a sorcerer. Man's witchcraft, therefore, has not the absolute secrecy, the character of a hidden, sinister knowledge, which is essential in the women's witchcraft. And another point: the fact that the ndăce

I A certain group of men sorcerers is said to live in the north of Nupe, whose activities are much more like the women's witchcraft, that is to say strongly organized, evil, and always deadly. Their witchcraft, however, is not based on the principle of invisibility and the separation of soul from body, but on a specific bullroarer-magic, called in Nupe vugu-vugu, which is said to give the sorcerers power to kill from a distance. My limited, and so far only second-hand, evidence about this special 'sorcerer society' does not allow me to form any opinion as yet. 
is considered the master of witchcraft makes this witchcraft more part of the general system of professional magic. Professional magic is very highly developed among the Nupe. Woodcutters and welldiggers, farmers and blacksmiths, and of course also hunters, have their special professional magic which is unknown to outsiders and the tradition of which is carried on in certain families. But hunters are, on the whole, more mysterious people. Their whole life is different from the 'normal' life of the villagers: they often live for a considerable time some distance away from the village and away from the familiar cultivated land; they carry out their dangerous work in the uninhabited bush where there are spirits in every tree, in every pool of water, and perhaps in every animal they encounter. The hunters have their special taboos, and elaborate magical rites before and after the hunt. But above all, the idea of making oneself invisible must be closely associated with this profession, with the hunter's unnoticed stealing upon the beasts of the bush. We understand, therefore, that the ndáce came to be regarded as a master of witchcraft. But we also understand that this type of witchcraft is not yet something very specific, and something that falls completely out of the framework of normal social life. It is only a sort of extended, though perhaps stronger, general magic.

\section{3}

The women's witchcraft, the 'real' witchcraft, is bound up specifically with night and invisibility, and with the concept of the human soul. The Nupe believe that every human being has two souls. One soul is called rayi, the word they have for life in general. And it is in fact the 'life soul' of man, with which one lives, with which one sees and hears the things of the world, and with which one dreams when asleep. The second soul is called fifingi, ' shadow', and like the shadow it is an image of the human body. As a rule it stays with the body and life soul, but it may be separated from it under certain conditions, the normal condition being sleep and dream. Dreaming of a man (who is alive) means that this man's fifingi was separated from his body when he was asleep, and came to you, and your sleeping soul, your sleeping ráyi, was able to see it. In the normal case this separation of the fifingi from the sleeping body is the work of the guardian spirits of man who 
WITCHCRAF'T AND ANTI-WITCHCRAFT IN NUPE SOCIE'TY 429 thus give man an opportunity to see, in the dream, beyond the border of earthly life. But witches can produce this separation, as it were artificially, as they please, and they can send out their fifingi at night time as an invisible agent of their unholy wishes, to cause nightmares, and to 'gi rayi', to 'eat' other people's life souls. '

It is implied in such a belief that it is not the concrete person of the witch which does all these things. On the contrary, the human body of the witch remains asleep in her house and betrays nothing of the secret of its master. You cannot come into the house of a witch at the time when she is engaged in her nightly work and prove her to be (or not to be) a witch. If you wake her up, the fifingi would come back to her at once-space and time matter nothing to the fifingi. The same seems to apply to the initiation into witchcraft. When a woman wants to become a witch she goes to another woman whom she knows to be a witch, or directly to the official head of the witches. And apparently without any complicated initiation she soon becomes a witch herself. But her visits would not be of the concrete, real type as in the case of the sorcerers, but again visits carried out at night time by the fifingi.

A woman who thus becomes a witch does not exercise her power independently, all by herself. To become a witch means to enter the ind găcizi, the organized 'order' of the witches. At night time, the Nupe say, the witches meet outside the village, under a tree, and hold there their unholy councils, in which they decide about the common plans. Every member of the 'order' is held to co-operate, that means to contribute to the common work by procuring, in turn, a human victim. In case counter-magic frustrates the attempts of a witch, she would resort to one of her own kin; for it is believed to be easier for a witch to exercise her power over her own flesh and blood. But often enough would the witches rave against each other, for rivalry, quarrels, and ill feeling are said to be a common feature in the 'order' of witches.

All this, elaborate and precise as it looks, is of course only ' theory'. But the reality to which this theory claims to refer is no less theoretical, no less imaginary. The 'order' of invisible members, the meetings

I There is a certain inconsistency in this 'theory'. For in certain cases, more frequently in the case of male witchcraft, it is not the fifingi which is sent out, but a spirit over whom the witch has gained power, and whom she (or he) uses in the same evil way. 


\section{WITCHCRAFT AND ANTI-WITCHCRAFT IN NUPE SOCIETY}

of witches known and visible only to one another, the shadow-souls on their nightly errands leaving behind a perfectly normal sleeping body -almost every element in this elaborate imaginary structure eludes the grasp of empirical reality. Again and again we come across the same idea, the same leitmotiv in Nupe witchcraft, namely the idea that it is impossible to bring the activities of witchcraft down to the standard of ordinary life. We understand the enormous psychological power inherent in such a belief which, to formulate it once more, safeguards itself from all tests, and even criticism.

Yet at some points the imaginary world of witchcraft must come into contact with, must, as it were, cut across the world of empirical facts. There seem to be three such points of transition.

(I) First of all we have the question of the social personality of the alleged witch; in other words, the question of the invisible witch's representation in the flesh. The allegation of witchcraft is not made entirely at random. There seem to exist certain loose, social, and general human criteria which render one woman more likely to be a witch than another. I found on the whole three such criteria: a married woman is suspected more readily than an unmarried one; the older a woman is the stronger is the suspicion, and the stronger is said to be her alleged power of witchcraft; and, finally, witchcraft is apt to be linked with the factor of social antagonism to the obtaining order. For example, I found a very general suspicion of witchcraft in the case of the wife of a man who was the descendant of the dispossessed former pagan chiefs of the place. And it was not so much the idea of his conscious grudge against the political 'usurper' which made him and his family suspect of the subterraneous, anti-social, activities of witchcraft, as the fact that he and his kin represented, in a changed Mohammedanized society, the original layer of a suppressed culture and religion.

(2) Another 'point of transition' between the imaginary wotld of witchcraft and the everyday world is embodied in the conviction of the Nupe that the alleged witch must herself be fully aware of being a witch. Although the visits to a fellow witch, and the meetings of the 'order' of witches, are carried out by the invisible shadow-soul, the one concrete, tangible, element at least is assumed to exist, namely a conscious intention to become, and to act as, a witch. If, therefore, 
WITCHCRAFT AND ANTI-WITCHCRAFT IN NUPE SOCIETY $43 \mathrm{I}$ a person convicted of being a witch denies all knowledge of such intention, she is, for the people, just lying. But how then 'under the hectoring suggestion of the . . . whole social environment the accused is no longer certain of herself and solves the mental conflict by willingly submitting to the ordeal', or even confessing directly, is a fact well known in the history of witchcraft among savage as well as civilized races. ${ }^{\text {I }}$

(3) The most striking 'transition' is represented in the figure of the official head of the women witches to whom we referred already in our schematic chart. The ènà găcizi of Bida or other large places in Nupe, i.e. the largest and best organized 'orders' of witches, had an official head, titled lelú. And whereas the witches in general were unknown, mysterious, and invisible, the lelu was an official person, known to everybody, and recognized by the town authorities and the king of Nupe. I am using the past tense because the office of lelu does not exist any more in the Mohammedan capital or in the large villages of Nupe. Yet the evidence I obtained of this institution is positive enough to include it in this account. According to this evidence the lelu was not only the head of the witches but also the official head of all the women in town who supervised the market, organized the common work of the women, and arbitrated in quarrels among the female population of the place. ${ }^{2}$ Although possessing the strongest power of witchcraft the leli was supposed to make use of it for good purposes only; in the case of war, for instance, she was to brew a certain medicine which would make the men of the town invincible. Now these qualities of the lelu define the role which she played in society: possessing the power of witchcraft, but using it only for good, being head of the women in the imaginary night-world of witchcraft, but at the same time also head of the women in the real workaday world, the lelu' is the type of person the community needs for discovering witches, and for fighting their secret anti-social activities. For this purpose in

1 Robert H. Lowie, Primitive Religion, p. $3^{6}$.

2 The same type of office exists in Bida to-day, entrusted to a woman who holds the title of sónya (from the Hausa word sarauniya, queen). The sónya is elected by the women of the town, and recognized by the town authorities (including to-day the European authorities). But all my informants stressed the point that originally there was no sónya in Bida or Nupe, but only one head of the womenthe lelu. 
432 WITCHCRAFT AND ANTI-WITCHCRAFT IN NUPE SOCIETY fact this curious office is created. King or village chief appoints the lelu, entrusting this office to a convicted but repentant witch who seems sufficiently trustworthy for this responsible position. At any rate, she would be an easy object for official supervision. Through her concrete and accessible person society gains a hold on the secret, intangible powers of witchcraft. The lelu' is to check the activities of her fellow witches and to restrain the too obnoxious or too violent ones amongst them. She is to help the chief to find a guilty witch, and she is personally responsible for the behaviour of the members of her 'order'. One never heard of a lelu who, once appointed, neglected her duties. But it stands to reason that a lelu always found means to fulfil her responsibility towards the community, and to discover the demanded victim. And it is equally evident that as a head of the women she will always remain in direct enough contact with the sources of public opinion to let her steps be directed by this irreproachable advisor.

\section{4}

The fact that witchcraft is at work in the community becomes manifest through one class of phenomena: disease, or more exactly mysterious disease, the nature of which it seems impossible to identify. Yet quite a number of different criteria must come together if the effect of witchcraft is to be established unquestionably. The victim of a witch would first of all have bad dreams, nightmares, feel mysterious pains in head and body, and eventually fall sick. In his dreams he would see the person who has bewitched him, and he would cry out her name in the sleep or the delirium of the disease. Yet not until this happens five times is it considered a real proof of witchcraft. Moreover, the soothsayers who are always consulted in the case of a mysterious disease or bad dreams would come independently to the same conclusion. All ordinary cures which might have been tried earlier and which naturally would have failed would now be abandoned, and a new course of action would be taken. This would not be a personal or family matter any more; it would now become the concern of the whole community, and the chief would be approached to take the necessary action.

In Nupe society there exist two different methods of fighting witchcraft which are made use of in different circumstances. The first, more simple, method is applied locally and ad hoc to the individual case. 
WITCHCRAFT AND ANTI-WITCHCRAFT IN NUPE SOCIETY 433 The second method is general and in a sense 'prophylactic', and is intended to attack witchcraft at the roots.

Let us start with the first method. When witchcraft has been identified in the way we were describing, and when suspicion has turned against a definite person, the procedure is comparatively simple-the witch-finding at least is no problem. It involves no special paraphernalia, and no showy display of a special ritual apparatus. The chief, possibly helped by the lelu, carries out all the necessary steps: he summons the alleged witch, he asks her to confess her evil deeds, and he orders her to make good the wrong she had committed. Finally the witch would be fined heavily. In the case of repetition, however, or in case the witch refuses to save her victim while there is still time, or, what amounts to the same, proves herself unable to do so, she would be expelled from the village for ever. As a rule the chief, at any rate with the help of the lelu, is said to recognize a witch without fail. But the witch may have to undergo an ordeal as well which would eventually convict her. This ordeal consists in the drinking of a certain medicine called wasa which, in the ordinary case, would be a very efficient cure for snakebite. Yet should a witch drink it, she would be killed by a snake within a fortnight. The village chief may make use of this fatal ordeal, but he would never dare to condemn a witch to death; he would be much too afraid of bringing the revenge of the whole ènà gácizi on the village. Only the Etsu Nupe, master of a special, most powerful magic as he is, is strong enough to brave witchcraft, and in his town he would have an unrepentant witch beheaded in public, on the market square. For other chiefs or local heads the expulsion of the witch from the village remains the most severe punishment they can inflict. And in the Bida witchcraft case of 1932 the head of the town-ward in which the three alleged witches were living in fact ordered their expulsion from his part of the town. The fact that this order was then cancelled by the superior authority of the alkali (judge) of Bida and the Emir himself was the immediate reason for the outbreak we referred to at the beginning of this article.

But there may be cases of witchcraft of a more complicated and more obnoxious type. No such clear indication of the guilty person would be possible, a great number of such mysterious diseases which nobody could identify would occur, and a number of people would 
434 WITCHCRAFT AND ANTI-WITCHCRAFT IN NUPE SOCIETY

fall victim to the power of the witches. In such a case the second antiwitchcraft method would be brought into play. The great number of cases, and fatal cases even, of alleged witchcraft is essential. There must be, this is the rule, more than one or two deaths in the village, should the first method of occasional help be abandoned definitely, and the frontal attack of the second method adopted for a systematic, and in a sense lasting, cleansing of the community. Against the system of witchcraft which threatens to gain the upper hand a definite system of anti-witchcraft is mobilized. It is entrusted to a special organization: to the 'secret society' of the ndǎkó gbòya'.

A few words must first be said about this secret organization of witch-finders. 'Secret society' is perhaps not quite the correct term; for the ndăkó gbòyd represents something between the organization of a kinship group in which a secret knowledge and practice is vested, and a 'society' proper, a voluntary association that is, of which (theoretically) everybody can bećome a member. Yet like the 'real' secret societies the ndákó gbòyá is secret only in so far as its inner organization and its esoteric proceedings are concerned. The society as such is well known and even recognized officially. It is, as we shall see presently, built definitely into the political structure of Nupe kingdom. Ndǎkó gbòyá means 'spirit gbòya', literally ' ancestor gbòya' yet there are (at any rate to-day) no ancestral ideas involved in this belief. I The initiates of the ndăkó gbòyá are said to possess power over these spirits; they can make them appear in a certain magical ceremony, materialized in dancing masks of uncanny appearance. And it is through the supernatural knowledge and power of these spirits that the members of the society are able to exercise their control over witches and witchcraft. The practitioners of the ndákó gbòa' are scattered all over Nupe country. They are found to-day in five or six different places; whether there have been more originally I am unable to decide. Yet in all these places there is the definite tradition-and a tradition strongly supported by the evidence of other culture elements

I The Nupe frequently use the word ndăkó, pl. ndăkóż, lit. grandfather or ancestor, for 'spirits' in general, and also for certain magical objects linked with these spirits, e.g. the bullroarer, vugì-vugì, is also called a ndăkó. 
WITCHCRAFT AND ANTI-WITCHCRAFT IN NUPE SOCIET'Y 435 -that the people who practise the ndăkó gbojá to-day have either come originally from the same place, namely from Kusogi Danci, on the southern bank of the Niger, or else have obtained, purchased, in fact, the secret of the ndăko gbojad from there. In this place KusogiDanci there still resides to-day the head of the society, the majiz dodo, the 'master of the evil spirit' (Hausa?), and those who want to be admitted to the society have to apply to him. His headship over the organization is again an official one, and his office and title are confirmed by the Etsu Nupe himself.

I have not had an opportunity of actually witnessing an initiation into the ndákó gbòya. But I found very detailed data about the initiation in one of the ndăkó gbojyd villages, Shehe Ndawu, where the family group which represents the secret society had acquired the 'membership' in comparatively recent times so that the circumstances of the procedure are still fully remembered. Three generations ago the ancestor of the present family-head went to Kusogi Danci to be initiated into the secret of the ndakko gboyá. At that time, they said, there were a great many witches in the country, and their ancestor, who was a very wise and clever man, decided to become a member of the ndăkó gbòyá, and thus bring relief to the community. He had to undergo a very severe initiation which included, besides the 'theoretical' training, a very rigid discipline and even bodily chastisement. The training and the probationary period lasted for five years and he had to pay the equivalent of ten pounds for the initiation. Eventually he returned home, a member of the ndăkó gbòá, a practitioner of its rites, and brought with him, as symbols and instruments of the magical practice, the paraphernalia of the ndăkó gbòya cult.

These paraphernalia are (I) the asiri ède, the 'secret of the dress', i.e. the white cloth mask in which the spirit makes his appearance. It is a huge cylinder of cloth, some is feet high, which hangs down from a circular wooden ring fixed on a long wooden pole. The man who represents the spirit stands inside the mask, covered completely by the cloth; he carries the pole in his hands, and by moving it up and down, and performing all kinds of evolutions with it, he produces the dance movements of the mask. (2) A certain medicine called wak ${ }^{2}$ which is

${ }^{2} W a k a$ is a corrupt form of the Hausa wanka, to wash, which is heard fairly frequently in the countries south of Hausa proper. It is surprising that both the 


\section{WITCHCRAFT AND ANTI-WITCHCRAFT IN NUPE SOCIETY}

kept in a special sacred pot of vaguely human shape is another essential cultic implement. Before starting the ndăkó gbòyá ceremony the actors of the ritual wash themselves with the medicine and drink a little of it. It is characteristic that this anti-witchcraft medicine is said to possess exactly the same qualities as the medicine which one takes in order to become a witch: it produces invisibility and separates the shadow-soul from the body. If the ceremony were performed without using this medicine first, it would be reduced to a mere dance, without magical power and without its deeper meaning. Again, then, we find the same idea alive: that in order to encounter, or to fight witchcraft one must possess witchcraft oneself. 'Only through Beelzebub can you cast out devils', as Dr. Evans-Pritchard puts it in a similar context. ${ }^{\text {I }}$ Finally there are a number of magical implements which as tradition has it were brought from Kusogi Danci as part of the ndákó gbòya outfit. The type of material culture which they represent proves their origin from the area where the whole ndăkó gbòya institution is said to have originated, the Niger valley. But they have no real relation to the ndǎkó gbòya. They represent elements of an additional, quasi secondary, magic, magic of a general and unspecific type-procuring help for barrenness or ordinary diseases, producing rain or protecting property from thieves. For us they are of special significance in so far as one implement amongst them, the egba Tsoede, the sacred chain of the ancestor-king of Nupe Tsoede, represents here as everywhere else in Nupe country the symbol of royal power and of the 'king's own magic'. It impresses on the ndăkó gbòya conspicuously the stamp of its relation to the paramount political authority of the country, to the king, or Etsu, of Nupe. ${ }^{2}$

All these sacred implements are kept in a special sacred 'shrine', a small hut inside the compound, and form the inalienable property of the family. They testify that from the day when the ancestor of the present keepers brought them to the village, the family was entitled to practise the ndǎkó gbòja, and to practise it for the sake of their witchname of the medicine, and the title of the head of the ndakko gbòya society, should be Hausa in origin. Yet I must refrain here from drawing any ethnological conclusions from this fact.

I 'The Zande Corporation of Witchdoctors', Journal of the Royal Anthropological Institute, vol. 1xii, p. 323.

${ }^{2}$ See my articles in Africa, vol. viii, no. 3, and Man, 143, 1935. 
WITCHCRAFT AND ANTI-WITCHCRAFT IN NUPE SOCIETY 437 craft-ridden country. It is interesting to note, however, that for the family itself, and for the one village community of which this family forms a part, the ndǎkó gbòyá has also another meaning: it had become a general magical cult performed regularly once a year; and as such an annual local cult it has lost its exclusive relation to witchcraft. Its specific magic has become an object of general local worship, its keepers became 'priests', and with the original idea have fused ideas of a local guardian spirit, and even of ancestor worship. To follow up this point, however, would lead beyond the scope of this discussion.

Let us turn, then, to the specific anti-witchcraft organization embodied in the ndăkó gbòyá. It works, as we have already mentioned, through the medium of a special ceremony in which the helpful spirits are made to appear and to rid the village from the evil of witchcraft. This ceremony is more or less everywhere the same. At dawn the masks of the ndáko gbòya, one to four in number, appear in the village. Nobody knows, of course, or is supposed to know, who is inside the masks; and certainly nothing in the acting of the masks, or in the weird sounds which they utter, betrays the human origin. Each mask is accompanied by two gógã, ' interpreters', who, unmasked (real human beings therefore) communicate and interpret to the community the wishes of the spirits. They carry big sticks with which they drive away everybody who comes too near the mask. The spirits never appear all together; they come and go one after the other, and the sudden disappearance of one mask in one place, and the unexpected, bewildering appearance of another mask in quite a different place, stresses their unearthly type. 'The spirits are numberless, they spring from the ground, and are swallowed by the ground', say the Nupe. This orthodox belief is perhaps not shared equally by everybody. There is no doubt that there are sceptics among the onlookers, people who 'know better', and who look down or pretend to look down on the ceremony as on an obsolete and slightly ridiculous hocus-pocus. But once the mask comes near them and bends its huge body over them, all scepticism seems gone, and they run away as fast as they can-they laugh, some of them at least, but they run nevertheless. And when I tried to test the seriousness with which they regarded this make-believe of masks and spirits, and offered food to the dancer in the mask (whom I knew very well), everybody at once commented on my faux pas, and was 
anxious to inform me that, as I ought to have known by then, "spirits don't eat'.

During the whole day, from dawn to nightfall, the spirits dance in the village on the market square where all the people are assembled. And sometimes they make unexpected excursions through the streets of the village, and even enter a house, to make quite sure that nobody is staying away. On the market place the musicians play and sing; the men stand or sit round, watching the ceremony; it is not really their affair; it is, above all, the women's ceremony. All the women are present: the young girls form the chorus, and the old women dance round and round the masks, shaking their rattles, and singing the songs of the ndákó gbòya. There is one song that runs as follows:

'A yì 'yà cì kúso dà,

Eyà yì lo rè.'

'One does not call (him) friend when he comes to stay in the bush,

A friend (he) is when he leaves.'

In these lines which the women sing the whole meaning of the ceremony is expressed. The spirits are the deadly enemies of the womenof those among them, that is, who may be witches. But who knows which will be the victims? The spirits' stay means danger, their departure relief. They intimidate and threaten, and ultimately punish. The punishment forms the climax of the whole ceremony, the final act of the drama of the ndăkó gbòyá. It takes place at night, after a day of ever-increasing excitement and fear: suddenly, in the middle of a dance, a mask would bend down its terrifying figure over some woman, and that means that the spirit has found a victim. The 'interpreters' would at once seize the woman and carry her away, out of the village, to a place in the bush nearby. Here the alleged witch is put to a cruel ordeal: she has to scratch the earth with her fingers till blood comes out under her nails; this is then taken as a proof of her guilt. Being thus convicted the witch can either buy herself freeand the older she is the more expensive it would be-or she is killed in the bush by the 'spirits'. One after the other the suspected witches are carried away and punished, and eventually, when the work is all done, the spirits leave the village again, and disappear in the dark of the bush which they sprang from, 'swallowed by the earth'.

Space forbids a detailed description of this ceremony. But I would 
WITCHCRAFT AND ANTI-WITCHCRAFT IN NUPE SOCIETY 439 stress one point: although, as we shall hear presently, the original, unadulterated ndǎkó gbòyá has been made impossible to-day, and although in the larger places Mohammedanism and modern ideas have partly undermined the old beliefs, there is no doubt that this ritual still holds its sway over the minds of the people. You can actually see it with your eyes, above all in the behaviour of the women. You see it in the manner in which the old women lay the customary offerings of money at the feet of the dancing mask. It is a mere formality to-day, an offering of pennies, and tenths of pennies. But it is still done voluntarily, and it is done with a reverence and a humbleness which betrays the essentially unchanged attitude.

\section{6}

There is a short myth linked with the ndăkó gbòya which explains, and, at the same time, in the manner of myths, confirms the cult and its organization by means of the customary reference to ancient happenings. A certain king of Nupe, the myth tells us, had a mother who constantly interfered with his rule and the exercise of his authority. Whatever he did or ordered to be done was frustrated by her magical influence. So finally he sought the help of a magician. The magician ordered him to bring twenty pieces of cloth; this cloth the magician sewed together in the shape of the long cylinder of the ndákó gbòyamask. He made his special magic over it, and then the cloth flew up into the air, suddenly dropped down over the king's mother, and mask and woman disappeared for ever. ${ }^{\mathrm{I}}$ All the relevant facts of the ndäkó gboyd ritual are thus underlined in the mythical account: first, the paraphernalia of the cult, the uncanny cloth-mask in which the spirits appear; second, the fact that the ndǎko gbòya is invoked against women, against old women who mysteriously interfere with the proper order of things; and finally, the fact that the ndăkó gbòya represents a kuti nyá 'tsu, a ' magic of the king'.

This last point brings us to the question of the authority entitled to mobilize the activities of the ndăkó gbòyá, and to the problem referred

I In this myth will be noticed also a certain deprecatory reference to matriarchal ideas. There exists in fact definite evidence for such a transition from matrilineal to patrilineal succession in the system of Nupe kingship and chieftainship as the mythological account appears to comment on. 
to earlier in the discussion, the relation between the general political organization of the country and the activities of the ndăkó gbòya society.

There are two possible ways of invoking the help of the ndáko gboya: first, the initiative comes from the afflicted place itself. The village elders and the chief decide the matter, and then send a special ritual messenger to the nearest village where members, or ' priests', of the ndăkó gbòya live, to ask them to perform their ceremony in this particular village. The ndǎkó gbòya people do so, and after having performed the ritual, after having warned or fined, threatened of punished the witches they return peacefully to their own home. The person of the 'ritual messenger' is not without interest. It is the ndazzo of the village, i.e. the priest of a certain religious cult called gunnu, the most vital religious cult of Nupe in fact, which undertakes to procure fertility and crops, health and childbirth, in short, which secures prosperity and general well-being for the community. The cult itself is concerned primarily with nature, and the general order of life and world. But in the person of its priest it extends its authority also over the special dangers of witchcraft, over the evil and anti-social influences, that is, which come from man himself. ${ }^{2}$ And there is another element in this : the ndazzo holds a very special position in the village community. He is an 'elder', but apart from his religious office he takes no part in the general political or social administration of the community. He is chosen because of his miraculous birth, and he remains, all his life, inviolable and unpunishable. Now it is obvious that this office of a ' ritual messenger' to the ndăkó gbòyá people must imply the conferring of confidential information about the suspicions which the village itself has formed. In the case of an ordinary man, even of the chief, such an office would easily involve the reproach of partiality, danger to prestige and possibly life, and above all danger to the general social peace in the community. The sacred person of the ndazzo, however, who stands above the laws and standards which rule the ordinary social life, imparts to his responsible office the same character of sacredness and of lofty impartiality.

The second method of mobilizing the ndǎkó gbòa society loses all contact with the actual needs of the afflicted community. It amounts

${ }^{2}$ My full account of the gunnu cult will appear in the Journal of the Royal Anthropological Institute. 
WITCHCRAFT AND ANTI-WITCHCRAFT IN NUPE SOCIETY 44I to nothing less than a 'decree from above'. It is in this connexion that the secret society shows its full power, and that its relation to the political structure of Nupe kingdom becomes manifest. The procedure is this: at a certain time of the year, usually about harvest time, the head of the ndăkó gboya' would appear at the king's court and, maintaining that the activities of the witches in the country have increased to a dangerous degree, he would persuade the king of the necessity to send the ndǎkó gbòyá people down to the various villages to rid them from the plague of witchcraft. When the Etsu agrees, and he always agrees, the head of the society mobilizes the branches in the country, and the various ndákó gbòy groups appear suddenly in the villages, perform their dances and 'discover' and punish witches. After some time the result is invariably this: the terrified women, learning that the ndăkó gboya' is in the neighbourhood, either flee and hide in the bush, or collect money to buy themselves free collectively. They send the money to the place where the ndákó gbòya is performing, and by this they secure that in their own village the ndakko gbòa people would only perform the harmless dance ceremony, and omit the witch-hunting. In any case the community would be plunged in unrest, households would be dissolved, the women would neglect their duties, money would become scarce, till eventually a number of village chiefs would come together, collect a large sum of money, up to $£ 20$, and bring it to the king beseeching him to recall the ndăkó gbòya. Three times has the king to recall officially the ndákó gbòya people till they obey. But at last they return, and the majĩ dodo appears again at the king's court, this time to settle the financial question: of the 'profits' the Etsu receives one-third, the ndákó gbòyá society keeps two-thirds. Suffice it to say that the average amount of money thus made and distributed used to be $£ 300$. The economic success is, moreover, specially safeguarded by the feature of fixing the date of the ceremony at harvest time, when money is plentiful everywhere in the country.

It is a significant fact that the ndăkó gbòya, the 'serious' ndăkó gbòya' at any rate, is never practised in the capital of the kingdom. Here the king, helped by the lelu, can control witchcraft very well himself-this is the official explanation. But there is more behind it: in the capital, in the king's own town, the socially as well as economically disorganizing influence of the secret society can obviously not be allowed. The 


\section{WITCHCRAFT AND ANTI-WITCHCRAFT IN NUPE SOCIETY}

ndákó gbòy supported, as it is, by the political authority, is to be a weapon in the hands of the king, and not a weapon which may tum against him and endanger his own interests. In Patigi, the small Nupe Emirate on the southern bank of the Niger, the ndákó gbòya' is actually performed in the ' king's own town' regularly every year; but there it has quite a different function, and appears only in its harmless form as an annual feast and dance ceremony.

The use of the ndăkó gbòyá as an economic and political weapon came to an end in $192 \mathrm{I}$, when the administration of Nupe Province had to forbid the ndăkó gbòya altogether. For these ceremonies which after the war had reached a tremendous scale became a ruthless regular exploitation of the people. The secret society in co-operation with the Emir of Nupe (a Mohammedan Emir) ' discovered' so many witches and 'delivered' so many villages that the economic situation of the whole country was upset, and that there was practically no money left for taxes. The villagers are well aware of the unscrupulous economic exploitation to which the practice of the ndǎkó gbòyá has lent itself. Yet they will tell you, with a certain tone of regret and even reproach which it is impossible not to hear, that there now exist no means against witchcraft any more in Nupe, 'sei Soko', save God-save the rather vague, far-away, 'idle' High-God. Only the Etsu of Patigi, they would add, who 'kept his ndǎkó gbòya' (Patigi belonging politically to Ilorin Province did not come under the ban of the ndákó gbòya') can do something against witchcraft; for the ndǎkó gbòya' is "the only sure means of protection'.

\section{7}

Out of the great number of theoretical problems which emerge from the data outlined here, I may be allowed to formulate two in conclusion.

The first problem refers to a question of history and ethnological distribution but bears in its final issue on an essential sociological aspect. Like many other culture traits in Nupe the practice of the ndákó gbòya is not common to the country as a whole but was limited as we have seen originally to one area. I cannot attempt in this article to demonstrate in detail the significance of this area on the southern bank of the Niger as a centre of diffusion for the general 
WITCHCRAFT AND ANTI-WITCHCRAFT IN NUPE SOCIET'Y 443 stratification of Nupe culture. The problem for us here is a more specific one: we have a certain ritual, a certain form of magic, limited originally to one local group, but spreading gradually in a very specific way all over the country. The magical power which the people of this small group may have possessed and which apparently was believed by the other tribal groups of the area to be more powerful, more effective than what they themselves possessed of such magic, was sought by these other groups. The keepers of the secret, perhaps a small alien group which had migrated into the area, are then incorporated into a larger system of tribal co-operation. Their secret is purchased, their knowledge is sought, and other people become disciples and initiates of their special system of magic. The result is the curious combination of family knowledge and secret society. A new organization crystallizes to which everybody can be admitted, and which gradually penetrates country and tribe. The new organization undertakes a definite obligation towards the community at large, namely to perform, for the community, its special rites. And in return the community allows this group of people to impose their own terms upon those who seek their help. But as we saw this social transformation has been influenced in a very special way by the additional factor of the centralized political system of the country. The organization of anti-witchcraft magic became a political weapon by means of which the king exercised a special spiritual as well as economic power over the country. The co-operation for a specific purpose between the two groups developed into a co-operation between three partners. And the bonds of sentiment and interest which gave rise to the original co-operation were made to serve the wider scheme of co-operation embodied in the political system. The new partner, the king, had to give something in return. And what he gave was not only the support of his official authority but something more intimately related to the character of this whole organization, namely the support of his special ancestral magic: we remember the sacred chain, and the other implements of what we called 'additional' and 'secondary' magic. The need of the community for a strong anti-witchcraft magic-the fact that a certain group possesses this magic-and then the political organization which brings the two together under its own auspices, cementing its own structure with this interplay of need and need-satisfaction-these are 


\section{WITCHCRAFT AND ANTI-WITCHCRAFT IN NUPE SOCIETY}

the main motives which shape the organization of this threefold partnership. I

The second problem is essentially psychological. It relates to the discussion at the beginning of this paper of the nature of witchcraft. It is impossible, though, to deal here with problems of such general and widely spread application as, for instance, the problem of the sexual antagonism implied in the Nupe distinction of the ' real' witchcraft of the women and the less dangerous 'black magic' of the men. But a related problem which is particularly well documented in the Nupe attitude towards witchcraft can be approached here, I hope, successfully. The most striking and surprising feature in the attitude of the people towards witchcraft is the fact that a certain amount of witchcraft is considered quite natural. Always and everywhere we hear the same expression, that witchcraft has to be checked only in case it 'becomes too bad'. We remember that the anti-witchcraft organization is mobilized only when the evil influences of witchcraft have demanded more than two victims; and we remember that the lelu is expected to suppress only the too dangerous and too obnoxious of her fellow witches. The idea of anti-witchcraft is not to stamp out witchcraft completely but merely to limit it to a "reasonable" degree.

If we tried to understand this we should have to realize one thing: whatever may be the efficiency of a system of magic, or quite generally of supernatural protection, there will always be a limit to it which nobody will deny. Mysterious, incurable diseases will occur. There will always be, for instance, the night-the dreaded night when the spirits walk about and kill men. There will always remain those evil influences of the world: wild beasts, the dangers of the bush, sudden death, and also dreams and nightmares. It is mere common sense to admit the impossibility of suppressing completely the "evil in the world'. You could not do it, and it would be foolish, nay, frivolous, to pretend to be able to do it. You have after all to be a realist. One could reply, of course, that the evil of which we are speaking here represents only a very special variation of evil, and not the

I It is a social partnership which is very typical of the ways in which a political system makes use of existing 'bonds of sentiment and interest'. I have described an analogous development in the sphere of native jurisdiction in my article in Man. 
WITCHCRAFT AND AN'TI-WITCHCRAFT IN NUPE SOCIETY 445 philosophical ' evil in the world' to which our theoretical implication could apply. But it amounts, I believe, essentially to the same. The belief in witchcraft is part of this comprehensive 'philosophical' attitude of man towards the evil in the world. We called the belief in witchcraft a belief safeguarding itself against being 'found out', against being proved or refuted by empirical means. Now here another such belief safeguards the existence of those evil influences of witchcraft and exempts them from the ordinary general maxim of life which is to eliminate injurious influences. Speaking practically, this 'realistic' system of thought saves man from false hopes and disappointment. Or to put it more philosophically, this system of thought which allows for an ultimate $x$, for a remainder of unaccountable freedom in the scheme of the world, saves the balance of such a comprehensive scheme and order of the world. Admitting that somewhere within this framework of life the laws which rule life, the principles of protection from evil, do not apply, it saves the existence, and the possibility of such safe guiding laws and protecting principles. We admit, then, that somewhere in the network of life the 'abnormal' will prevail, and will prevail not only de facto, as a constant defect in our world order, but de jure so to speak, i.e. as a recognized factor in this order. But in doing this we re-establish the distinction between what is normal and what is abnormal, between what should be and what should be destroyed, a distinction on which our whole conceptual attitude to life and its problems is ultimately based.

S. F. NADEL.

\section{APPENDIX}

Except the last paragraph, this account has been obtained in Bida, the capital of Nupe, from a highly educated (Mohammedan) school-teacher there. The supplementary information on the anti-witchcraft society contained in the last paragraph was obtained in the primitive Nupe village on Jebba Island.

Nyizàgizì à-gá è-nya 'gà-o. Lelú wừ-gá yì

The women they (are) those practising witchoraft. Lelu she (is) the one (who) is the nũsa nyá gǎcizi-o. Ábèke nyizàgi gá è̀-wă gã̃ nw'à-nya 'gà nã, head of the witches. If a woman should be wanting that she will practise witchcraft, nw’á jî-ù dā eba Lelú, gă nw'è-wă egà ì nya. Găcizì eyé she would go to the Lelu, saying, she wants witchcraft to practise. The witches at 
gá shí a jĩ-á yèkã̀, cigbề ta-o, à ci á shawra jĩ, 'bà na à night they would meet, under a tree, they then would discuss the place where they gá à-lo 'fougá nã.

would be going that day.

Ezàzì gầ găcizì a è-gí nákằ nyá 'zà wángi. Àmâ niní The people say, the witches they are eating flesh of human beings. But one by niní ácĩ-gá à è-wu 'zà-o. 'Zà na nw'á tò 'fo-gá nã, u one thus it is they are killing man. The person whose turn it would be that day, she

á dà 'wă 'zà ndoci wu, nwu ci á nàkă-u lá bě, a ci á would go (and) look for somebody to kill, she then would bring his body, they would gắ gì. Kágama u de 'zà wu à, a jĩ-á wũtsó divide (it and) eat. If she finds no person to kill, they (i.e. the witches) would

wu, a nàkã-u sà gì. Găci ndoci nw’á jĩ nw’á egi-ú kill herself, they divide her flesh and eat. $A$ witch may do (this:) she would her ko yegi-ú ko yágí-ú wu, nw’á nàkă-u lá bě, a sà child or her brother or her grandchild kill, she would his body bring, they divide

gì. Àmâ ábèke găcizì à gá è-wă éwó nã, á jĩ-a ezà (it and) eat. But if the witches they should want money, they would take

lá dā kîn ndoci, dă kứ. a person to another country, go (and) sell (it).

Nupecizì a yà gàskíya ke găcizì de cigbè na è-lá fù nã. Àmâ a

The Nupe believe that witches have medicine that makes fy. But they

è-fù dàgà kótónci èzì băbo dā ebà ke Kení nã, mínì arefying from for example this town to the place where the Hausa (are), in the yèshi-o, à à-dà $3^{\text {ì }}$ ebà lá tĩ à. middle of the night, they will return before it is light.

Ábèke a gá è-wă ezà à wu na, a fé 'wă, 'zà na de If they should want a person to kill, they are looking for a person which has láfíyà à nã. Kángá à gẵ, a de cigbè na è-lă gì ráyi health not. Then one says, they have medicine which is causing to eat the soul (life) dégi dégi nã. A fé gì ráyi hárí ezà á-tsu. Kángá a èlittle by little. They keep on eating the soul till the person is dead. Then they are lá ú dà gì-o, àmâ kágắ, á de 'zà na è-tấ nya na à, taking him, go (and) eat (him) but if they find a person who is sick not,

á jĩ-a fifingi nyá 'zà yì de láfíyà nã nwa. Kángá u they would the shadow-soul of the man (who) possesses health catch. Then he gá yă è-nya tắ, kángá nw’à-fé gì ráyi, dégi would begin to be sick, then she (the witch) would keep on eating the soul, little 
dégi, hárí nw'á-tsu. Ábèke à gá de 'zà na de cigbè by little, till he is dead. If they should find a person which possesses medicine găcizì nã, nw’à jĩ u tàymako, u gá sā, nw'á tsu bè à. (against) witches, it would him (this person) help, he would recover, he would die not.

Ábèke găcizì a da bo na, a da tá yà 'zà na jĩ Ndăkó When witches are there, one goes (and) tells the people who make the Ndako gbòyá nã, táko táko; a bé dàgà Kusògi Dànci; a tá yà 'tsu Nupe. gboya, down river; they come from Kusogi Danci; one tells the Etsu Nupe. A gá tá yà 'tsu Nupe; za na è-jĩ Ndăkó gbòyá nã, a One would tell the Etsu Nupe; (and) the men who are making the Ndako gboya, they ci gã: a bé, gútá jĩ $u$ bé. A ci be tá then say they (will) come, three it makes (that) will come. They then come (and) tell yà zìtsu, a ci gẵ tô, kuti u bé aní. Kángá kuti wũ gá the village chief, they then say well, the magic has come. Then the magic itself would $\mathrm{dzu \tilde { }} \mathrm{dã}$ 'dě bo. A ci gã: găci a da bo kata kàzã; kata appear in the mask. They then say: witches there are in such and such a house; in such kàzã u dã-o. Ndǎkó gbòyá ci á nwa u. and such a house it (the mask) enters. The Ndako gboya then catches her (the witch).

A lá u wu gàci. Efè nw'á ló 'zì kpátá. A de láfiya They kill the witch. A wind it would enter the whole village. They have health

kángá.

then (from then on).

\section{Résumé}

\section{LA SORCELLERIE CHEZ LES NOUPÉ}

Les croyances des Noupé en matière de sorcellerie se manifestèrent spécialement en février 1932. A ce moment trois hommes, considérés comme sorciers, furent tués par les habitants de Bida en fureur. Les renseignements recueillis révèlent l'existence de deux types de sorcellerie: la 'vraie' sorcellerie, celle des femmes qui est toujours nocive et antisociale; et la sorcellerie des hommes, supposée plus faible, moins dangereuse et qui se rapproche davantage du type de la magie ordinaire. Chez les Noupé les idées relatives à la sorcellerie sont englobées dans une croyance à l'organisation d'une véritable association de sorciers, dont le chef prend une importance particulière, du fait qu'il est reconnu par le chef du village.

Il y a deux moyens de combattre la sorcellerie: d'abord par des procédés applicables dans les cas individuels; et en second lieu, au moyen d'un système compliqué dont l'emploi est confié à une société secrète, le ndăkó gbòyd. Cette association et la place qu'elle occupe dans la société est analysée en détail.

La conclusion formule deux problèmes théoriques: le problème social de la coopération originelle entre la communauté dans son ensemble et la société secrète; le problème psychologique, impliqué dans le système de pensée des Noupé, qui semblent accepter le fait qu'il est impossible d'éliminer complètement la sorcellerie, et qu'un certain degré de sorcellerie est presque naturel. 